\title{
Infectious bronchitis virus inhibits activation of the TLR7 pathway, but not the TLR3 pathway
}

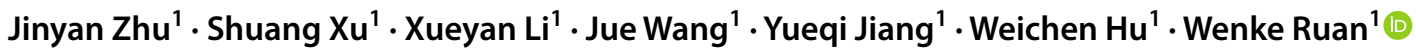

Received: 18 November 2019 / Accepted: 29 April 2020 / Published online: 10 June 2020

(c) Springer-Verlag GmbH Austria, part of Springer Nature 2020

\begin{abstract}
Various strains of infectious bronchitis virus (IBV) cause different forms of infectious bronchitis with different clinical signs. Here, primary chicken embryo kidney (CEK) cells and specific-pathogen-free (SPF) chickens were infected with three pathogenic IBV strains, and it was observed that the TLR7-MYD88 pathway was inhibited but the TLR3-TIRF pathway was activated. After treatment with poly(I:C)-LMW, poly (I:C)-LMW/LyoVec, and Imiquimod, the replication of IBV was significantly suppressed after $24 \mathrm{~h}$. However, treatment with TLR3 pathway inhibitors such as Pepinh-TRIF, celastrol, chloroquine, and BX795 resulted in increased replication of IBV after $36 \mathrm{~h}$. These results also showed that chloroquine and celastrol were most effective inhibitors of the antiviral response at $48 \mathrm{hpi}$.
\end{abstract}

Infectious bronchitis is a contagious disease of poultry caused by infectious bronchitis virus (IBV), a member of the genus Gammacoronavirus [16]. Different strains of IBV cause various pathologies $[10,16]$. Avian Toll-like receptor (TLR) 3 and TLR7 recognize viral RNA in endosomes and induce immune responses [20, 24]. Avian melanoma differentiation associated gene 5 (MDA5) is a RIG-I-like receptor (RLR) that recognizes long viral RNA in the cytoplasm [28]. Previous studies showed that TLR3 contributes to the host defense against severe acute respiratory syndrome coronavirus (SARS-CoV) and porcine epidemic diarrhea virus (PEDV) [2, 23]. Stimulation of TLR3 hindered murine coronavirus infection, but stimulation of TLR7 did not affect murine coronavirus production [18]. It was also shown that MDA5 is critical for host defense during infection with murine coronavirus [29]. IBV strains may different in their pathogenicity and induce different immune response. Here, three IBV strains associated with three classic types of pathogenicity were chosen to explore potential differences in the innate immune responses they induce.

Handling Editor: Roman Pogranichniy.

Wenke Ruan

wenkeruan@hotmail.com

1 Beijing Key Laboratory of Traditional Chinese Veterinary Medicine, College of Animal Science and Technology, Beijing University of Agriculture, Beijing 102206, China
The AH and TM strains of IBV were isolated from sick chickens with respiratory signs, kidney changes, and proventriculus changes from chicken farms. IBV strain H52 was obtained from QYH Biotech Company Limited, Beijing, China. Chicken embryo kidney (CEK) cells were prepared from the kidneys of 17-day-old specific-pathogen-free (SPF) chicken embryos and were cultured in six-well plates $\left(5 \times 10^{5}\right.$ cells/well $)$ at $37^{\circ} \mathrm{C}$. For viral infection, CEK cells were inoculated with IBV strain $\mathrm{AH}$, TM, or $\mathrm{H} 52$ at a multiplicity of infection (MOI) of 1 for $1 \mathrm{~h}$ at $37^{\circ} \mathrm{C}$. Mock-treated CEK cells were incubated with sterile saline solution without virus and then cultured under the same conditions. The cells were collected at $12,24,36$, or $48 \mathrm{~h}$ post-inoculation (hpi), and total RNA was extracted from the tissue samples and cells using TRIzol Reagent (Invitrogen, Carlsbad, CA). All experiments were performed in triplicate. The extracted

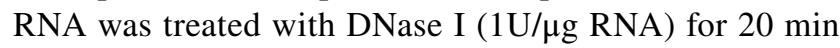
and then reverse transcribed into cDNA. The $20-\mu \mathrm{L}$ reaction mixture contained $2 \mu \mathrm{g}$ of total RNA, $0.5 \mu \mathrm{g}$ of anchored oligo (dT18), and $2 \mu \mathrm{L}$ of EasyScript RT/RI EnzymeMix in $1 \times$ ES Reaction Mix (Transgen Biotech, Beijing, China). The reaction mixture was incubated at $42{ }^{\circ} \mathrm{C}$ for $30 \mathrm{~min}$ and then at $85{ }^{\circ} \mathrm{C}$ for $5 \mathrm{~min}$. The initial RNA and DNA concentrations were determined using a spectrophotometer (NanoDrop Technologies, Wilmington, DE). $\beta$-actin (ACTB) was selected as a control because it is a stably expressed and frequently used reference gene. The qPCR reaction mixture contained $0.5 \mu \mathrm{l}(10 \mu \mathrm{mol})$ of each primer, $10 \mu \mathrm{l}$ of $2 \times$ UltraSYBR Mixture (CWBIO, Beijing, China), $8 \mu \mathrm{l}$ 
of nuclease-free water, and $1 \mu \mathrm{l}$ of the appropriate template cDNA. The primers used are shown in Table 1. All reactions were performed in triplicate on an Applied Biosystems StepOne Real-Time PCR System (Thermo Fisher, USA). The cycling parameters for this reaction were $95^{\circ} \mathrm{C}$ for $10 \mathrm{~min}$, followed by 40 cycles of $95^{\circ} \mathrm{C}$ for $10 \mathrm{~s}, 60^{\circ} \mathrm{C}$ for $30 \mathrm{~s}$, and $72{ }^{\circ} \mathrm{C}$ for $32 \mathrm{~s}$, with a final cycle of $95{ }^{\circ} \mathrm{C}$ for $15 \mathrm{~s}, 60{ }^{\circ} \mathrm{C}$ for $1 \mathrm{~min}, 95{ }^{\circ} \mathrm{C}$ for $15 \mathrm{~s}$, and $60{ }^{\circ} \mathrm{C}$ for $15 \mathrm{~s}$. Standard curves were obtained by plotting the crossing point, $\mathrm{C}_{\mathrm{q}}$, as a function of the logarithm of the plasmid DNA concentration for each target sequence. The copy numbers of cytokine genes were determined using standard curves and normalized to the copy number of the reference gene. An ELISA kit was used to determine the concentration of IFN $\beta$ in cell culture supernatants (Cloud-Clone Corp. Wuhan, China). To determine protein levels, CEK cells collected from the same virus-infected sample at different time points were lysed with RIPA lysis buffer (Beyotime Institute of Biotechnology, Beijing, China). These proteins were subjected to SDS-PAGE on a $12 \%$ acrylamide gel, and the separated protein bands were transferred to a PVDF membrane using a trans-blot (Bio-Rad, CA, USA). The membrane strips were tested for their reactivity with an anti-MYD88 antibody, an anti-TRIF antibody, an anti-NF- $\mathrm{kB}$ antibody, or a $\beta$-actin antibody (Cell Signaling Technology, CA, USA): For in vivo experiments, 40 fifteen-day-old SPF chickens were randomly divided into four groups (animal ethics approval no.
2017-02-13). They were challenged with $0.2 \mathrm{ml}$ of a virus suspension containing $10^{6} \mathrm{EID}_{50}$ of IBV strain $\mathrm{AH}, \mathrm{TM}$, or $\mathrm{H} 52$ or with $0.2 \mathrm{ml}$ of sterile saline solution. The kidneys of these chickens were collected at 5 days post-inoculation (dpi), since the virus titer in the kidney has been shown to reach a peak after 5-7 days $[3,19,27]$. The tissues were stored in liquid nitrogen and used later for RNA extraction and qPCR assays. To investigate the effect of innate immune molecules, agonists of TLR3, TLR7, and MDA5 and inhibitors of key molecules of the TLR3 pathway were added to CEK cells that had grown to $80-90 \%$ as instructed by the reagent manufacturer (InvivoGen, CA, USA) as follows: $5 \mu \mathrm{g}$ of imiquimod (a TLR7 agonist) per $\mathrm{mL}$ for $12 \mathrm{~h}, 10 \mu \mathrm{g}$ of low-molecular-weight (LMW) polyinosinic-polycytidylic acid (poly(I:C)) (a TLR3 agonist) per $\mathrm{mL}$ for $12 \mathrm{~h}, 0.5 \mu \mathrm{g}$ of poly (I:C)-LMW/LyoVec (an MDA5 agonist) per $\mathrm{mL}$ for $12 \mathrm{~h}, 10 \mu \mathrm{M}$ Pepinh-TRIF (a TRIF inhibitor) for $6 \mathrm{~h}, 5 \mu \mathrm{M}$ celastrol (an NF- $\kappa B$ inhibitor) for $1 \mathrm{~h}, 50 \mu \mathrm{M}$ chloroquine (an inhibitor of endosomal acidification) for $0.5 \mathrm{~h}$, and $5 \mu \mathrm{M}$ BX795 (a TBK1 inhibitor) for $6 \mathrm{~h}$. The cells were then washed with PBS, and their viability was tested using trypan blue staining. The treated cells were incubated at an MOI of 1 with IBV strain $\mathrm{AH}, \mathrm{TM}$, or $\mathrm{H} 52$ for $1 \mathrm{~h}$ at $37^{\circ} \mathrm{C}$ and washed again with PBS. Control CEK cells were infected with IBV without pretreatment and cultured under the same conditions. The cells were collected at $12,24,36$, or $48 \mathrm{hpi}$ for qPCR using a pair of primers specific for the IBV $\mathrm{N}$

Table 1 qPCR primers and amplification information

\begin{tabular}{|c|c|c|c|c|c|c|c|c|}
\hline Gene name & Primer sequence $\left(5^{\prime}-3^{\prime}\right)$ & $\begin{array}{l}\text { Product } \\
\text { size } \\
\text { (bp) }\end{array}$ & Accession no & Location & $\begin{array}{l}\text { PCR } \\
\text { efficiency } \\
(\%)\end{array}$ & $\begin{array}{l}\text { Correlation } \\
\text { coefficient } \\
\left(\mathrm{R}^{2}\right)\end{array}$ & $y$-intercept & Slope \\
\hline TLR3 & $\begin{array}{l}\text { F: GGAAATCTGTTTGGCCTTATACTG } \\
\text { A } \\
\text { R: TAAAACTGTGAGGTTTGTTCC } \\
\text { TTGC }\end{array}$ & 177 & NM001011691 & $661-837$ & 99 & 0.9907 & 48.126 & -3.534 \\
\hline TLR7 & $\begin{array}{l}\text { F: TAAAATTGCTGACCTAAGGGT } \\
\text { GTTC } \\
\text { R: CTTGCAACTTCGACCATATTCATC }\end{array}$ & 205 & NM001011688 & $1404-1608$ & 101 & 0.9988 & 45.289 & -3.610 \\
\hline MDA5 & $\begin{array}{l}\text { F: TAAGTGGAAATACAGGAGGAA } \\
\text { CAGA } \\
\text { R: TCTTTCCAACAGATGTTTCCAATA } \\
\text { C }\end{array}$ & 177 & NM001193638 & $726-902$ & 96 & 0.9973 & 46.618 & -3.984 \\
\hline IFN $\beta$ & $\begin{array}{l}\text { F: AAGCCTCCAGCTCCTTCAGAA } \\
\text { TACG } \\
\text { R: TGTTTTGGAGTGTGTGGGCTG } \\
\text { CTAA }\end{array}$ & 183 & NM001024836 & $123-305$ & 103 & 0.9986 & 44.855 & -3.190 \\
\hline IL-6 & $\begin{array}{l}\text { F: TTCGTTTATGGAGAAGACCGTGAG } \\
\text { R: GGTTCCTAGAAGGAAATGAGA } \\
\quad \text { ATGC }\end{array}$ & 197 & NM204628 & $682-878$ & 100 & 0.9978 & 46.76 & -3.452 \\
\hline$\beta$-actin & $\begin{array}{l}\text { F: GTTACCCACACTGTGCCCATCTAT } \\
\text { G } \\
\text { R: GTCACGCACAATTTCTCTCTCGG }\end{array}$ & 159 & NM205518 & $543-701$ & 98 & 0.9976 & 44.218 & -3.319 \\
\hline
\end{tabular}


gene (forward, ATGTGATGACCCGCAGTTTG; reverse, TTCCAGCTGTGCATTGTTCC) to determine the number of copies of the IBV genome.

Compared to the uninfected controls, at $12 \mathrm{hpi}$, TLR7, MDA5, and IFN $\beta$ mRNA expression was significantly upregulated by IBV strain AH. At $36 \mathrm{hpi}$, the expression of TLR3, TLR7, MDA5, and IFN $\beta$ mRNA was significantly downregulated in TM-infected cells. At 48 hpi, TLR3 mRNA expression was significantly upregulated by all three IBV strains, whereas TLR7 mRNA expression was significantly downregulated by all three strains. MDA5 mRNA expression was downregulated in cells infected with IBV strain H52. IL6 mRNA expression was downregulated by all three IBV strains at 48 hpi. No significant difference in IFN $\beta$ mRNA expression was observed among groups at 48 hpi. IFN $\beta$ protein expression was downregulated at $12 \mathrm{hpi}$ but upregulated at 48 hpi (Fig. 1A-F). The differences in mRNA and protein expression suggested that transcription or translation of IFN $\beta$ could be regulated by the virus.

Expression of the MYD88, TRIF, and NF- $\mathrm{KB}$ proteins was detected by Western blot. Compared with the levels in uninfected cells, the expression of MYD88 was significantly downregulated in all IBV-infected cells from 12 to $48 \mathrm{hpi}$. However, the expression of TRIF was significantly upregulated in all IBV-infected cells from 12 to $48 \mathrm{hpi}$. Moreover, at $48 \mathrm{hpi}$, the expression of both MYD88 and NF- $\mathrm{KB}$ was significantly higher in cells infected with IBV strain H52 than in those infected with strain AH or TM (Fig. 1G-I). Importantly, we found significant activation of the TLR3-TRIF pathway and inhibition of the TLR7-MYD88 pathway at 48 hpi by different IBV strains in CEK cells. Previous studies have shown the expression of innate immune molecules in chickens $[3,19,27]$. We found that TLR7 and IFN $\beta$ mRNA expression in the kidney was significantly downregulated in chickens infected with AH and TM (Fig. 1K and M). However, there was no significant difference in mRNA expression of TLR3 and MDA5 in any the experimental groups (Fig. 1J and L). The observed differences might be explained by the fact that more kinds of molecules are involved in the antiviral response in vivo than in vitro.

The replication of strain AH was significantly inhibited compared to the control from 24 to $36 \mathrm{hpi}$, whereas the replication of strain H52 was significantly inhibited after $24 \mathrm{hpi}$, and the replication of strain TM was significantly inhibited from 12 to 36 hpi (Fig. 2). All of the inhibitors that were tested promoted IBV replication after $36 \mathrm{hpi}$. After treatment with Pepinh-TRIF, BX795, or chloroquine, the rate of replication of IBV in AH-infected CEK cells was significantly higher than in control cells at $36 \mathrm{hpi}$, but the replication of $\mathrm{AH}$ in celastrol-treated cells was significantly higher at 48 hpi. After treatment with Pepinh-TRIF and BX795, the replication rate of IBV strain TM was significantly higher at 36 hpi. The rate of replication of TM was significantly higher at $48 \mathrm{hpi}$ after treatment with all four inhibitors. After treatment with chloroquine, the rate of replication of strain $\mathrm{H} 52$ was significantly higher at $36 \mathrm{hpi}$, and the rate of replication of H52 in Pepinh-TRIF-, celastrol-, and chloroquine-treated cells was significantly higher at $48 \mathrm{hpi}$. At $36 \mathrm{hpi}$, the most effective inhibitor of replication of IBV strain AH was chloroquine, but at $48 \mathrm{hpi}$, it was celastrol. At $36 \mathrm{hpi}$, the most effective inhibitor of TM was BX795, but at $48 \mathrm{hpi}$, it was chloroquine. From 36 to 48 hpi, the most effective inhibitor of $\mathrm{H} 52$ replication was chloroquine (Fig. 2).

Previous research has suggested that IBV strains differ in their pathogenic mechanisms [16]. TLR3, TLR7, and MDA5 play critical roles in the activation of the innate immune response to IBV infection [13, 24]. For example, TLR3 levels were significantly downregulated in the respiratory epithelial cells and lungs of 6-day-old chickens infected with the IBV Connecticut strain [11]. However, another report showed that TLR3 and TLR7 levels in the trachea and kidneys were upregulated from days 3 to 8 in 2-week-old SPF chickens infected with IBV strain M41 [8]. Several studies have shown that the expression of TLR3 and TLR7 after IBV infection decreases after the passage of the infectious virus, which demonstrates the ability of IBV to adapt to the host environment $[25,30]$. MDA5 has been shown to be upregulated in the trachea but downregulated in the kidneys [8]. Further research is required to clarify the complex regulatory mechanism in the kidneys after IBV infection [19, 27].

IBV has a single-stranded RNA genome, and TLR7 recognizes single-stranded viral RNA, subsequently activating an immune response $[9,17]$. Our results suggest that IBV inhibits the expression of TLR7, but the mechanism by which this occurs is unclear. Innate immune receptors are competitive determinants of cell fate [5]. In the case of IBV, in addition to the structural proteins, more than 20 nonstructural proteins and secretory proteins have important biological functions that still need to be elucidated. TLR3 activates an immune response after it recognizes viral double-stranded RNA [1]. We found that TLR3 was upregulated by IBV in CEK cells. Viral double-stranded RNA is synthesized in CEK cells late in IBV infection, so TLR3 probably plays an important role in the recognition of IBV during the late period of IBV infection. MYD88 and TRIF were the adaptor molecules of TLR7 and TLR3, respectively [17, 26]. Here, we found that MYD88 protein expression was significantly suppressed, but TRIF was significantly upregulated. There is an evident correlation between activation and inhibition of immune recognition receptors and signal pathway molecules. NF- $\kappa \mathrm{B}$ protein expression was upregulated at 48 hpi in cells infected with IBV strain H52, which is an efficient vaccine strain. This result might therefore identify another signaling pathway by which the immune response is activated after infection with H52, such as the TLR3 pathway [1]. In contrast to earlier reports, we found that IBV 
Fig. 1 Transcriptional regulation and protein expression of chicken TLR3, TLR7, MDA5, IFN $\beta$, MyD88, TRIF, and NF-KB in IBV-infected CEK cells and SPF chickens. (A-E) CEK cells were inoculated with IBV strain AH, TM, or H52 at an MOI of 1 . The cells were collected at $12,24,36$, or 48 hpi. The expression of chicken TLR3, TLR7, MDA5, IFN $\beta$, and IL-6 mRNA was detected using qPCR. (F) The expression of IFN $\beta$ protein in cell culture supernatants was detected using an ELISA assay. (G-I) The expression of MyD88, TRIF, $\mathrm{NF}-\kappa \mathrm{B}$, and $\beta$-actin proteins was detected using anti-MyD88, anti-TRIF, anti-NF- $\mathrm{KB}$, and anti- $\beta$-actin antibody. (J-M) SPF chickens were challenged with a 0.2 -ml suspension containing $10^{6} \mathrm{EID}_{50}$ of IBV, and the kidneys of these chickens were collected at $5 \mathrm{dpi}$. The expression of chicken TLR3, TLR7, MDA5, and IFN $\beta$ mRNA was detected using qPCR. Data were analyzed using unpaired $t$-tests or ANOVA, followed by Dunnett's multiple comparison test, using GraphPad Prism (GraphPad Software, San Diego, CA). The significance of the differences between the infected and mock-infected groups is indicated by the $p$-value
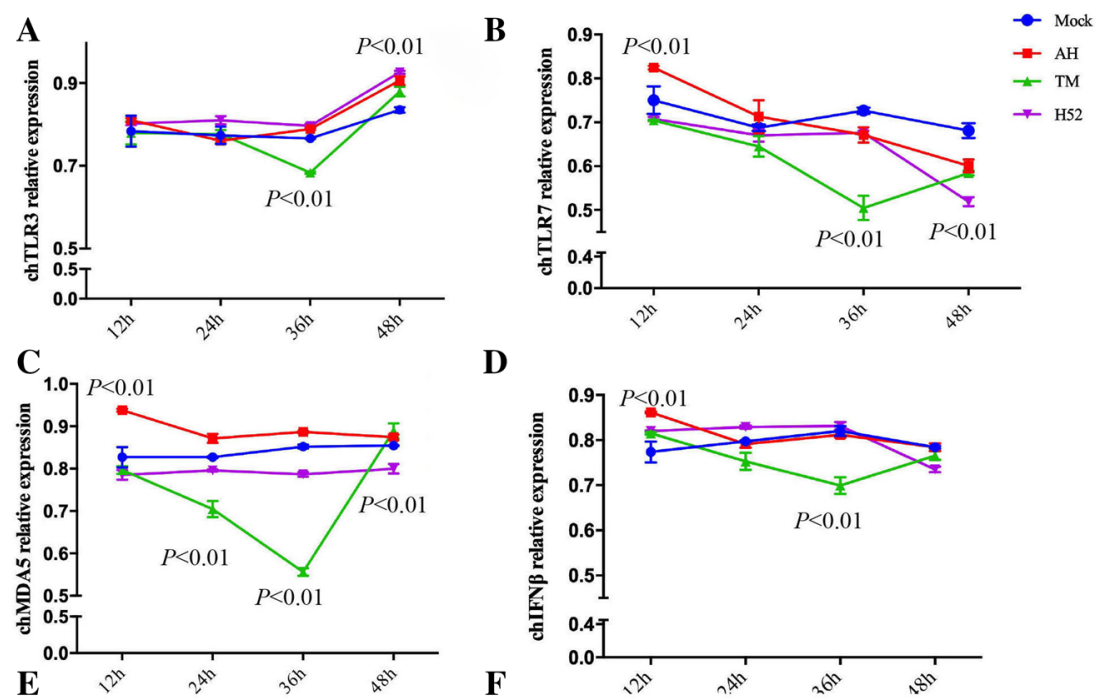

D
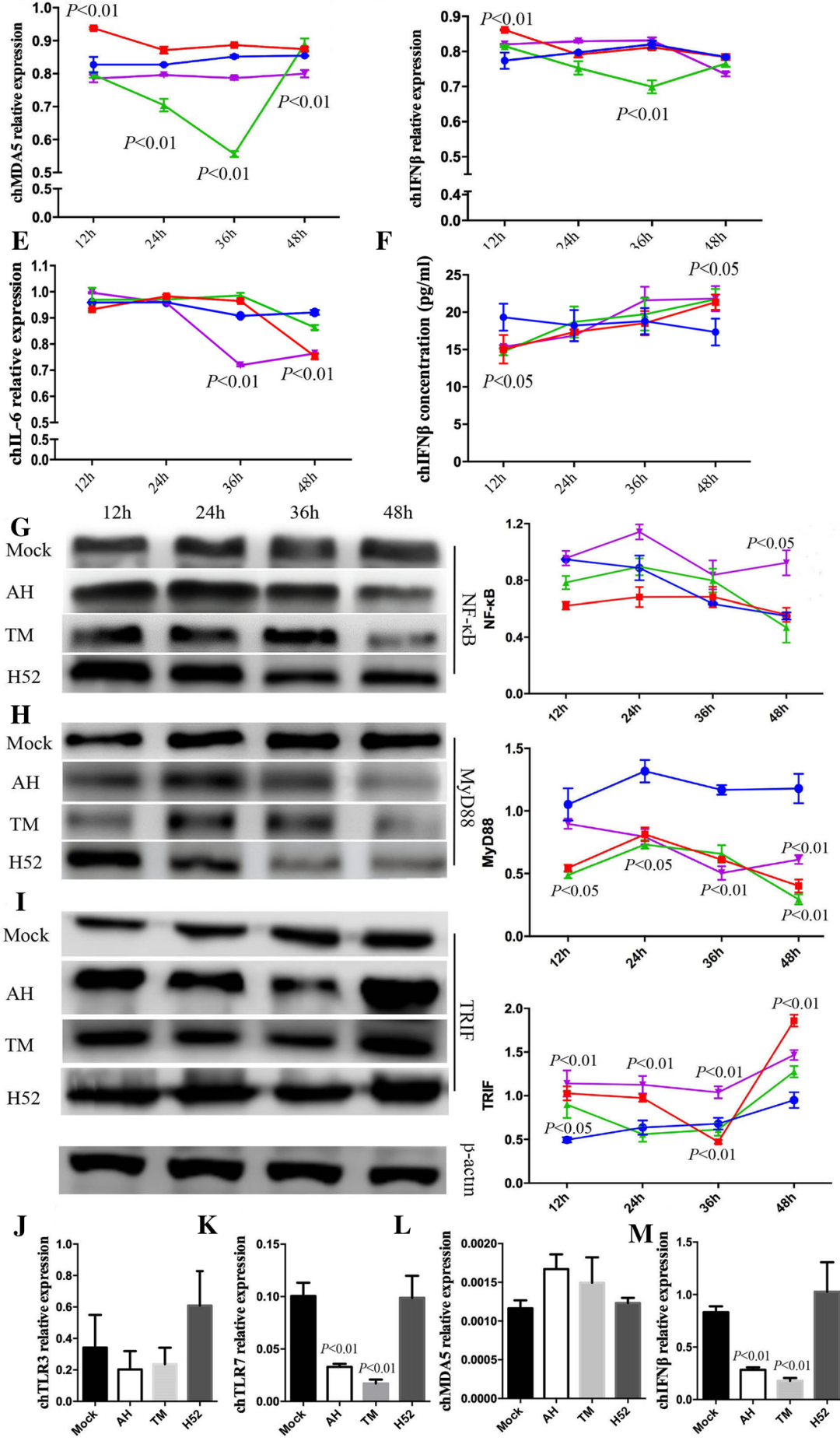

$\mathbf{L}$

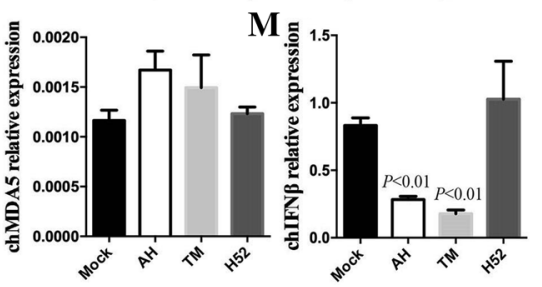


$\mathrm{AH}$
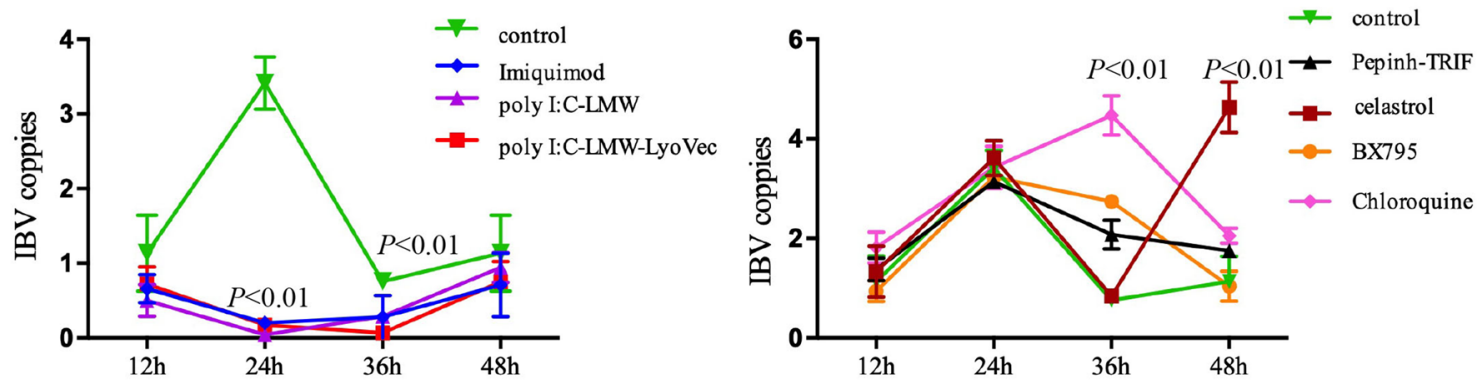

TM
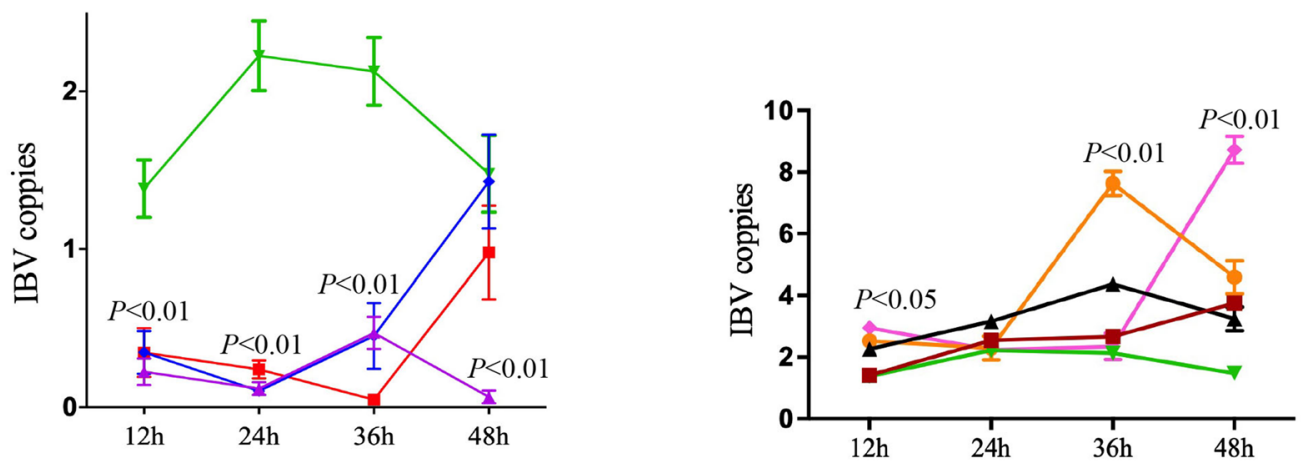

$\mathrm{H} 52$
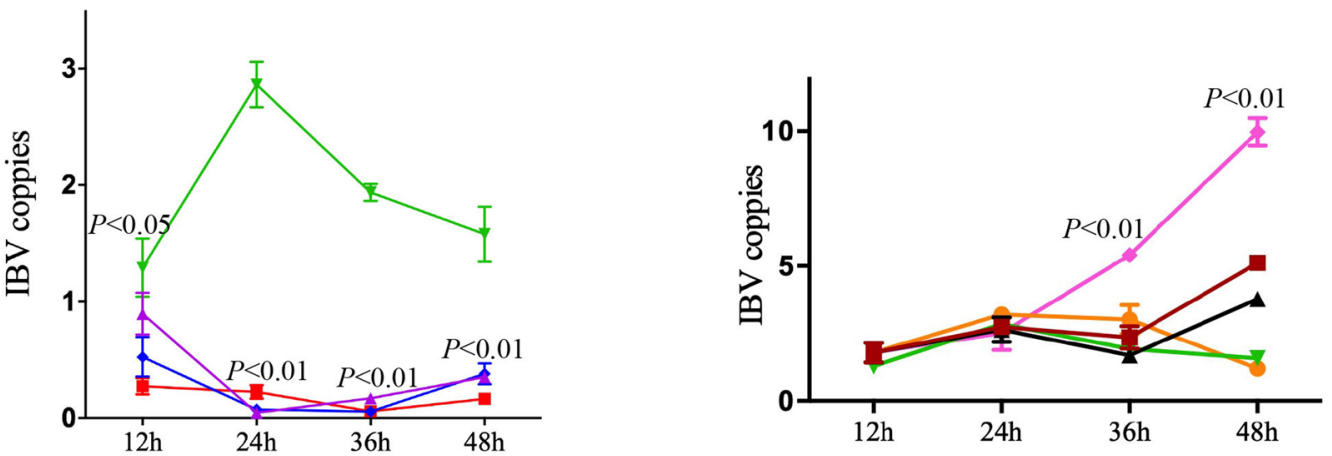

Fig. 2 The effect of agonists and inhibitors on the replication of different IBV strains. Agonists of TLR3, TLR7, MDA5 and inhibitors of key molecules of the TLR3 pathway were added to the CEK cells, which were infected with IBV strain AH, TM, or H52 at an MOI of 1. The cells were collected at $12,24,36$, or $48 \mathrm{hpi}$, and IBV N and

strains with different pathogenicity induced different levels of MDA5 mRNA [14], indicating that TLR3 is probably the main pattern recognition receptor (PRR) recognizing the IBV genome, rather than TLR7 or MDA5.

Imiquimod (also known as R837) is a ligand of TLR7 [15]. Poly(I:C) is recognized by TLR3 [12]. Poly(I:C)$\mathrm{LMW} / \mathrm{LyoVec}$ is a preformed complex consisting of poly(I:C)-LMW and the transfection reagent LyoVec. Naked poly(I:C) is recognized by TLR3, whereas transfected poly(I:C) is sensed by MDA5 [6]. Both showed a strong effect on immune activation in this study. We suggest $\beta$-actin mRNA expression was measured using qPCR. Data were analyzed using unpaired $t$-tests or ANOVA, followed by Dunnett's multiple comparison test, using GraphPad Prism (GraphPad Software, San Diego, CA). The significance of the differences between the treatment and control groups is indicated by the $p$-value

that the TLR3 pathway is the major immune pathway that inhibits early replication of IBV. TRIF and TBK1 are key molecules in TLR3 signaling pathway. Pepinh-TRIF contains a 14-aa sequence that corresponds to the sequence of TRIF [22]. BX795 inhibits the catalytic activity of TBK1/ IKK $\varepsilon$ by blocking its phosphorylation [4]. Celastrol is an effective inhibitor of NF- $\mathrm{BB}$ [21]. Chloroquine is an inhibitor of endosomal acidification [7]. Al of these compounds enhanced IBV replication after 36 hpi in this study, consistent with the signal transmission by these downstream molecules. Celastrol inhibited all of the IBV strains at 48 
hpi, since NF- $\mathrm{KB}$ is the downstream molecule of the immune pathway. In addition to celastrol, chloroquine also showed a strong ability to promote replication of IBV strains TM and H52. This suggests that endosomal acidification and RNA degradation are important for immune recognition of IBV. The three IBV strains tested showed different sensitivity to inhibitors. This study provides preliminary data on the immune responses induced by different IBV strains and their pathogenicity. Future studies can use these data to analyze the mechanisms underlying the variations in IBV pathology and immune responses. These data also can be helpful for future IBV vaccine research.

Acknowledgements We would like to thank the National Natural Science Foundation of China (\#31572499 to Wenke Ruan) for financial support.

\section{Compliance with ethical standards}

Conflict of interest The authors declare that they have no conflict of interest.

Ethical approval All applicable international, national, and/or institutional guidelines for the care and use of animals were followed.

\section{References}

1. Alexopoulou L, Holt AC, Medzhitov R, Flavell RA (2001) Recognition of double-stranded RNA and activation of NF-kappaB by Toll-like receptor 3. Nature 413:732-738

2. Cao L, Ge X, Gao Y, Ren Y, Ren X, Li G (2015) Porcine epidemic diarrhea virus infection induces NF-kappaB activation through the TLR2, TLR3 and TLR9 pathways in porcine intestinal epithelial cells. J Gen Virol 96:1757-1767

3. Chhabra R, Ball C, Chantrey J, Ganapathy K (2018) Differential innate immune responses induced by classical and variant infectious bronchitis viruses in specific pathogen free chicks. Dev Comp Immunol 87:16-23

4. Clark K, Plater L, Peggie M, Cohen P (2009) Use of the pharmacological inhibitor BX795 to study the regulation and physiological roles of TBK1 and IkappaB kinase epsilon: a distinct upstream kinase mediates Ser-172 phosphorylation and activation. J Biol Chem 284:14136-14146

5. Franz KM, Kagan JC (2017) Innate immune receptors as competitive determinants of cell fate. Mol Cell 66:750-760

6. Gitlin L, Barchet W, Gilfillan S, Cella M, Beutler B, Flavell RA, Diamond MS, Colonna M (2006) Essential role of mda-5 in type I IFN responses to polyriboinosinic:polyribocytidylic acid and encephalomyocarditis picornavirus. Proc Natl Acad Sci USA 103:8459-8464

7. Hart OM, Athie-Morales V, O'Connor GM, Gardiner CM (2005) TLR7/8-mediated activation of human NK cells results in accessory cell-dependent IFN-gamma production. J Immunol 175:1636-1642

8. He Y, Xie Z, Dai J, Cao Y, Hou J, Zheng Y, Wei T, Mo M, Wei $P$ (2016) Responses of the Toll-like receptor and melanoma differentiation-associated protein 5 signaling pathways to avian infectious bronchitis virus infection in chicks. Virologica Sinica 31:57-68

9. Heil F, Hemmi H, Hochrein H, Ampenberger F, Kirschning C, Akira S, Lipford G, Wagner H, Bauer S (2004) Species-specific recognition of single-stranded RNA via toll-like receptor 7 and 8. Science 303:1526-1529

10. Jordan B (2017) Vaccination against infectious bronchitis virus: A continuous challenge. Vet Microbiol 206:137-143

11. Kameka AM, Haddadi S, Kim DS, Cork SC, Abdul-Careem MF (2014) Induction of innate immune response following infectious bronchitis corona virus infection in the respiratory tract of chickens. Virology 450-451:114-121

12. Kawai T, Akira S (2008) Toll-like receptor and RIG-I-like receptor signaling. Ann N Y Acad Sci 1143:1-20

13. Kell AM, Gale M Jr (2015) RIG-I in RNA virus recognition. Virology 479-480:110-121

14. Kint J, Fernandez-Gutierrez M, Maier HJ, Britton P, Langereis MA, Koumans J, Wiegertjes GF, Forlenza M (2015) Activation of the chicken type I interferon response by infectious bronchitis coronavirus. J Virol 89:1156-1167

15. Lee J, Chuang TH, Redecke V, She L, Pitha PM, Carson DA, Raz E, Cottam HB (2003) Molecular basis for the immunostimulatory activity of guanine nucleoside analogs: activation of Toll-like receptor 7. Proc Natl Acad Sci USA 100:6646-6651

16. Lin SY, Chen HW (2017) Infectious bronchitis virus variants: molecular analysis and pathogenicity investigation. Int J Mol Sci 18:2030-2046

17. Lund JM, Alexopoulou L, Sato A, Karow M, Adams NC, Gale NW, Iwasaki A, Flavell RA (2004) Recognition of singlestranded RNA viruses by Toll-like receptor 7. Proc Natl Acad Sci USA 101:5598-5603

18. Mazaleuskaya L, Veltrop R, Ikpeze N, Martin-Garcia J, Navas-Martin S (2012) Protective role of Toll-like Receptor 3 -induced type I interferon in murine coronavirus infection of macrophages. Viruses 4:901-923

19. Okino CH, Mores MA, Trevisol IM, Coldebella A, Montassier HJ, Brentano L (2017) Early immune responses and development of pathogenesis of avian infectious bronchitis viruses with different virulence profiles. PLoS ONE 12:e0172275

20. Ruan W, An J, Wu Y (2015) Polymorphisms of chicken TLR3 and 7 in different breeds. PLoS ONE 10:e0119967

21. Sethi G, Ahn KS, Pandey MK, Aggarwal BB (2007) Celastrol, a novel triterpene, potentiates TNF-induced apoptosis and suppresses invasion of tumor cells by inhibiting NF-kappaB-regulated gene products and TAK1-mediated NF-kappaB activation. Blood 109:2727-2735

22. Toshchakov VU, Basu S, Fenton MJ, Vogel SN (2005) Differential involvement of BB loops of toll-IL-1 resistance (TIR) domain-containing adapter proteins in TLR4- versus TLR2mediated signal transduction. J Immunol 175:494-500

23. Totura AL, Whitmore A, Agnihothram S, Schafer A, Katze MG, Heise MT, Baric RS (2015) Toll-like receptor 3 signaling via TRIF contributes to a protective innate immune response to severe acute respiratory syndrome coronavirus infection. mBio 6:e00638-e1615

24. Vaidya SA, Cheng G (2003) Toll-like receptors and innate antiviral responses. Curr Opin Immunol 15:402-407

25. Xu Y, Zhang T, Xu Q, Han Z, Liang S, Shao Y, Ma D, Liu S (2015) Differential modulation of avian beta-defensin and Tolllike receptor expression in chickens infected with infectious bronchitis virus. Appl Microbiol Biotechnol 99:9011-9024

26. Yamamoto M, Sato S, Hemmi H, Hoshino K, Kaisho T, Sanjo H, Takeuchi O, Sugiyama M, Okabe M, Takeda K, Akira S (2003) Role of adaptor TRIF in the MyD88-independent tolllike receptor signaling pathway. Science 301:640-643 
27. Yang X, Li J, Liu H, Zhang P, Chen D, Men S, Li X, Wang H (2018) Induction of innate immune response following introduction of infectious bronchitis virus (IBV) in the trachea and renal tissues of chickens. Microb Pathog 116:54-61

28. Yu L, Zhang X, Wu T, Su J, Wang Y, Wang Y, Ruan B, Niu X, Wu Y (2017) Avian infectious bronchitis virus disrupts the melanoma differentiation associated gene 5 (MDA5) signaling pathway by cleavage of the adaptor protein MAVS. BMC Vet Res 13:332

29. Zalinger ZB, Elliott R, Rose KM, Weiss SR (2015) MDA5 is critical to host defense during infection with murine coronavirus. J Virol 89:12330-12340
30. Zhou Y, Yang X, Wang H, Zeng F, Zhang Z, Zhang A, Liu H (2016) The establishment and characteristics of cell-adapted IBV strain H120. Adv Virol 161:3179-3187

Publisher's Note Springer Nature remains neutral with regard to jurisdictional claims in published maps and institutional affiliations. 